\title{
"Abitare con sé stessi”. Dalla stanza sull'albero al Casello RAV (Reparto Alta Velocità) di Manerba del Garda (BS)
}

Sereno Innocenti

\section{Abstract}

La traccia di come un luogo possa trasformarsi in un 'luogo del cuore', si può ritrovare in un'intervista rilasciata dal Presidente della Biennale di Venezia (20 18) Paolo Baratta. Su questo principio con semplici ma fondamentali strumenti della rappresentazione (disegno manuale e maquette) si studiano 'microarchitetture', con spiccate caratteristiche paesaggistiche del sito che le ospita, atte a ricreare uno spazio personale con cui poter "abitare con sé stessi".

Parole chiave

sogno, curiosità, fantasia.

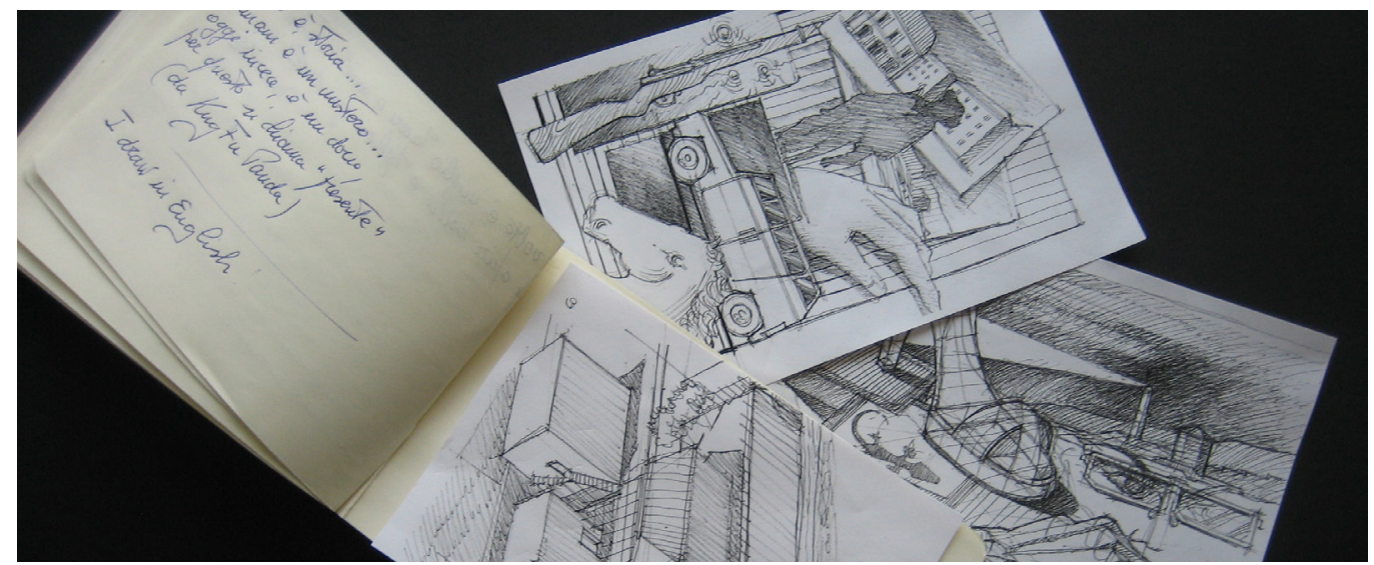




\section{Premessa}

L'urbanista e architetto americano Kevin Andrew Lynch, che ha concentrato la sua ricerca e la sua attività sulla percezione del paesaggio da parte della gente, sostiene: "tutti impariamo a leggere i luoghi così come si impara a leggere un libro. Leggere un luogo significa capire cosa vi accade, cosa vi è accaduto e cosa potrebbe accadervi, cosa significa e come ci si deve comportare, infine come è legato ad altri luoghi."

La traccia di come un luogo invece possa diventare anche un 'luogo del cuore', si può trovare in un'intervista rilasciata dal Presidente della Biennale di Venezia del 20 I8, Paolo Baratta, che al quesito rispose: "Ne ho davvero molti, alcuni li riconosco come tali dopo molti anni, non li battezzi al primo impatto. Luogo del cuore è una definizione intrisa di qualche sentimento, preferisco dire luogo del cuore riconosciuto, dire come parte di una realtà; questo in fin dei conti è il desiderio di tutti. Il senso dello spazio, un valore che dobbiamo riconoscere, più che d'atmosfera, preferisco parlare di quanto certi luoghi sanno dare facendoti riconoscere come destinatario de dono".

Su questi principii ogni anno, con gli studenti matricole del corso di Disegno, durante le prime settimane di studio, attraverso un 'test grafico-creativo', si sperimenta il disegno e il rilievo di una piccola architettura, con un forte carattere paesaggistico del sito che la ospita, da destinarsi a una sorta di 'pensatoio' o 'spazio personale', in cui abitare con sé stessi.

Fig. I. Cinema, scienza, tecnica e letteratura, possono diventare stimolo creativo e suggerimento comparativo per il progetto del microspazio in cui 'abitare con se stessi' (disegni a penn dell'autore).

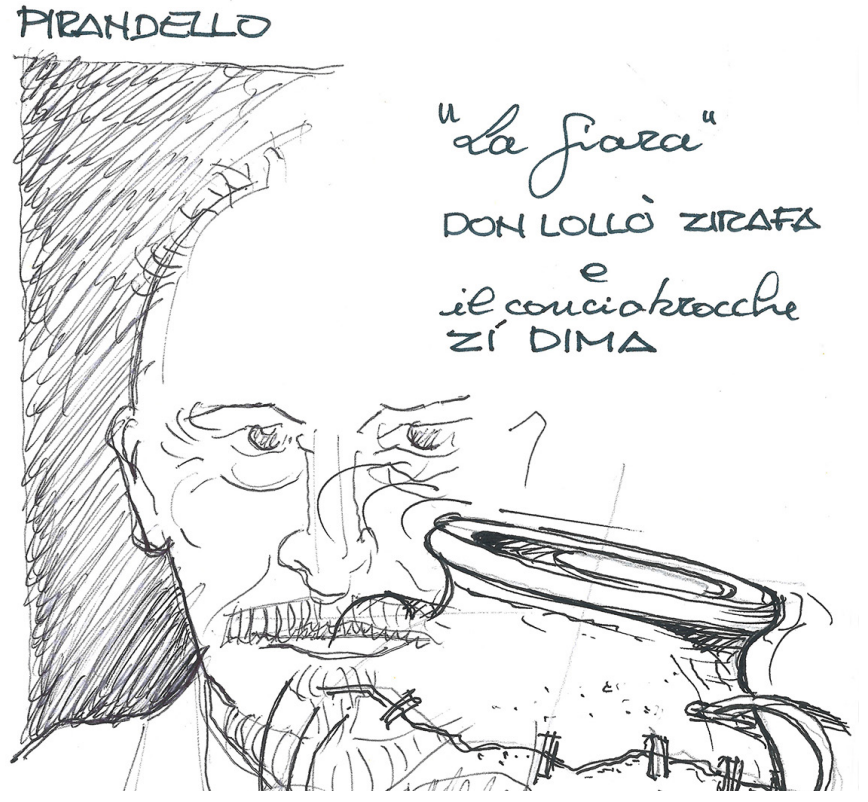

\section{Metodologia}

Lo spazio è studiato attraverso una ricerca in dicotomia tra ragione e sentimento, che contraddistingue il potenziale e futuro abitante del sito. Lo spazio della ragione, stigmatizzato dal bagaglio culturale e dalle possibili passioni intrinseche del singolo studioso, è disegnato manualmente attraverso schizzi, disegni tecnici e plastici analogici, atti a rappresentare quelle microdestinazioni d'uso rispondenti a funzioni non strettamente legate all'abitare, ma molto semplicemente si cerca di rendere questo spazio strettamente cucito sulla personalità del suo abitante/disegnatore. La risposta alle domande: chi ospiteresti o chi non vorresti ospitare in questo spazio; che musica si ascolta; che libro si legge; che film si vede; che opera d'arte si espone; che abito si indossa o che cibo e bevanda si gusta, diventa la cartina tornasole dello stato d'animo del possibile abitante di questo spazio. 
L'insegnamento del disegno ha sempre avuto un ruolo fondamentale nelle scuole di Ingegneria e di Architettura, e a volte e un po' impropriamente è considerato solo una disciplina artistica. Ma nelle scuole d'arte di un tempo, l'aula da disegno assumeva una configurazione simbolica persino nella topografica distribuzione degli spazi. Al suo interno la presenza dei disegni appesi alle pareti, maquette lignee, fregi architettonici e una ricca gipsoteca gli conferivano una particolare rappresentanza. L'aula, seguendo una tradizione ormai perduta, era dedicata a Minerva; dea del pensiero della razionalità, sbocciata dal cervello di Zeus, simbolo della progettualità al punto di ispirare a Ulisse il progetto per il suo cavallo di Troia. Questo concetto di spazio dove creare, suggerito dagli scritti di Attilio Pizzigoni, è quasi utopico in un tempo dove si pensa, si comunica e quindi si disegna digitalmente, ma all'interno dei laboratori di disegno, il progetto e il pensiero dovranno sempre essere tracciati dalla matita! "il sogno è come il maligno, non muore mai", sosteneva il regista Mario Monicelli, ed è nei sogni di ogni futuro architetto, di ogni futuro ingegnere, il progetto di grandi opere e grandi spazi, ma più i progetti sembrano semplici e ridotti, più complesse sono le soluzioni e si richiede una cura capillare nel dettaglio. Se esiste uno spazio personale, per piccolo che sia, ogni individuo, può diventare il miglior progettista di questo spazio, scegliendo naturalmente per quest'ultimo i migliori paesaggi in cui è ubicato e i migliori panorami su cui da esso potersi affacciare.

Fig. 2. Cinema, scienza, tecnica e letteratura possono diventare stimolo creativo e suggerimento comparativo per il progetto del microspazio in cui 'abitare con sé stessi' (disegni a penn dell'autore).

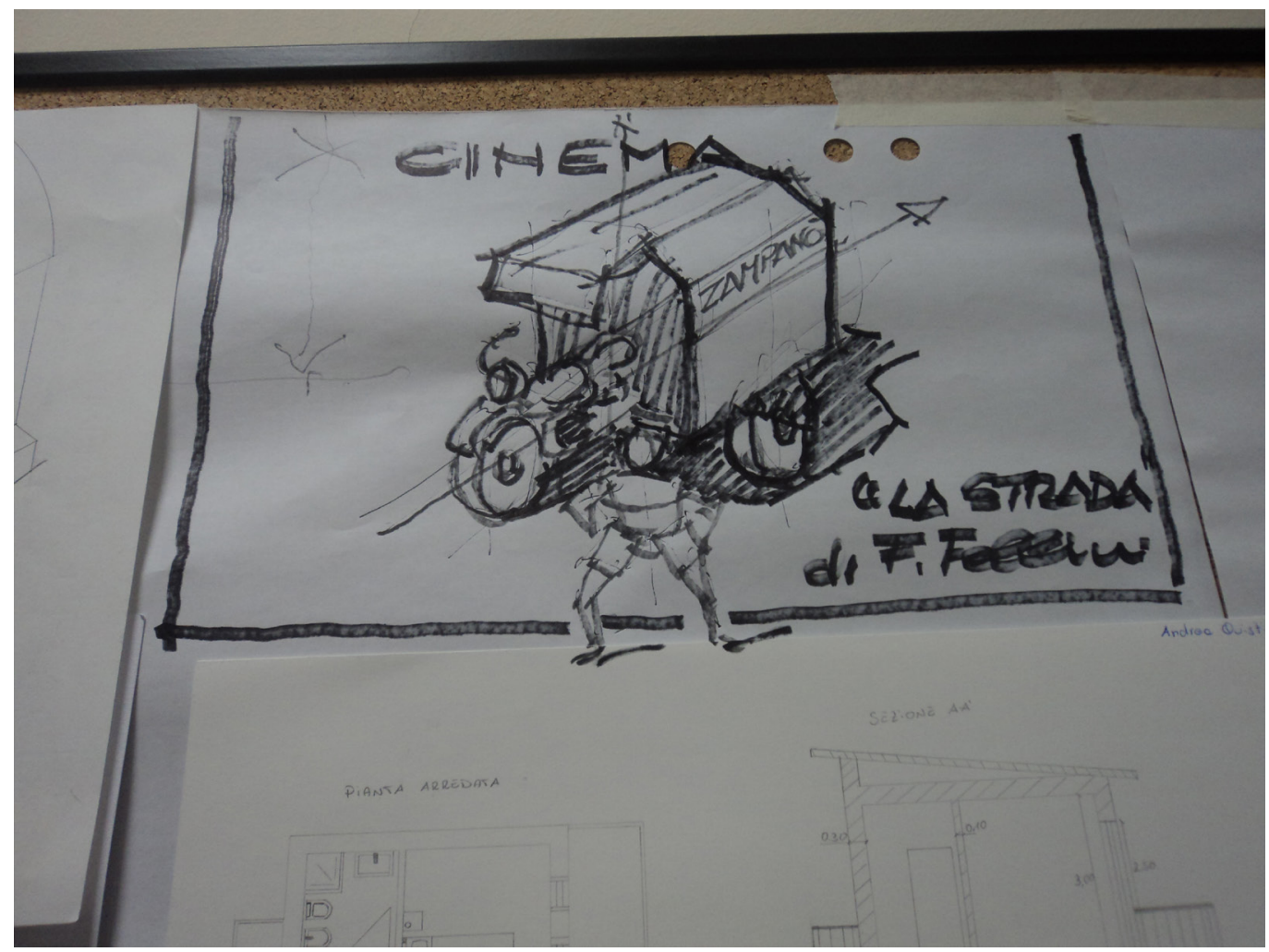

\section{I riferimenti culturali, dalla filmografia all'architettura}

Il cinema, la scienza, la tecnica, così come la letteratura e la filosofia, sono stati gli esempi sinottici e i suggerimenti della creatività per il progetto dello spazio per sé stessi (figg. I-3). Federico Fellini nel film La strada, con il quale nel 1957 vinse il premio Oscar per il miglior film straniero, disegna come era solito fare, una piccola 'casa viaggiante' per i protagonisti di questo suo capolavoro di celluloide. II cerbero saltimbanco e imbonitore Zampanò, magistralmente interpretato dall'attore Antony Quinn e Giulietta Masina, moglie del regista, nei panni di Gelsomina, vivono infatti nello spazio angusto di un motocarro a tre ruote, costruito 
appositamente sulla base della motocicletta Sertum, la cui parte telonata dello chassis, viene disegnata dal cineasta romagnolo, come un mostro terribile che li inghiotte e li divora. II motocarro diventa così la loro abitazione viaggiante, uno spazio dentro il quale vivono una malinconica vita di stenti, aggravata dall'affacciarsi sul paesaggio di un'Italia distrutta dalla guerra e dai bombardamenti. Se in metafora, dalle 'stelle' del cinema, passiamo alle stelle del firmamento, possiamo considerare quale altro esempio, di 'minima abitabilità' e con diverse condizioni di vita per l'assenza della gravità, gli ambienti della Soyuz che ultimamente ha riportato dallo spazio al Kazakhistan il comandante Paolo Nespoli e il suo equipaggio di astronauti. Anche la letteratura suggerisce tracce per microspazi. Luigi Pirandello, costruisce la sua celebre opera drammaturgica attorno a "la giara", dove Don Lolò Zifara e il conciabrocche Zi Dima, sono i protagonisti del palinsesto teatrale, parte del quale si svolge proprio all'interno di un grande otre oleario. Renzo Piano, nel 20 I3,'battezza' con lo stesso nome del filosofo greco che visse in una botte, Diogene, il progetto per la Vitra della "capanna da meditazione"; un'unità abitativa mobile ecosostenibile dalle ridottissime dimensioni ergonomicamente funzionali $(2 \mathrm{~m} 2 \mathrm{~m})$ dalla cubatura, che non supera i 3 metri cubi e dal peso di una tonnellata, costruendone un prototipo nel campus di Weil Am Rhein sul Reno. L'architetto in un'intervista dichiarò, che la dimora minima, era un tema che lo aveva ossessionato sin dagli anni giovanili dell'università. Altrettanto ardua e sullo stesso tema, è stata la sfida di un gruppo di studenti della Harvard Graduate School of Design, che hanno disegnato un "rifugio innovativo" in grado di resistere a temporali, nevi e venti alpini su un terreno refrattario dalla solidità come quello carsico. Con l'aiuto di architetti professionisti e ingegneri strutturali, è stato così realizzato in Slovenia sul monte Skuta un bivacco minimalista che porta all'estremo il concetto di panorama.

Fig. 3. Cinema, scienza, tecnica e letteratura, possono diventare stimolo creativo e suggerimento comparativo per il progetto del microspazio in cui 'abitare con se stessi' (disegni a penna dell'autore).

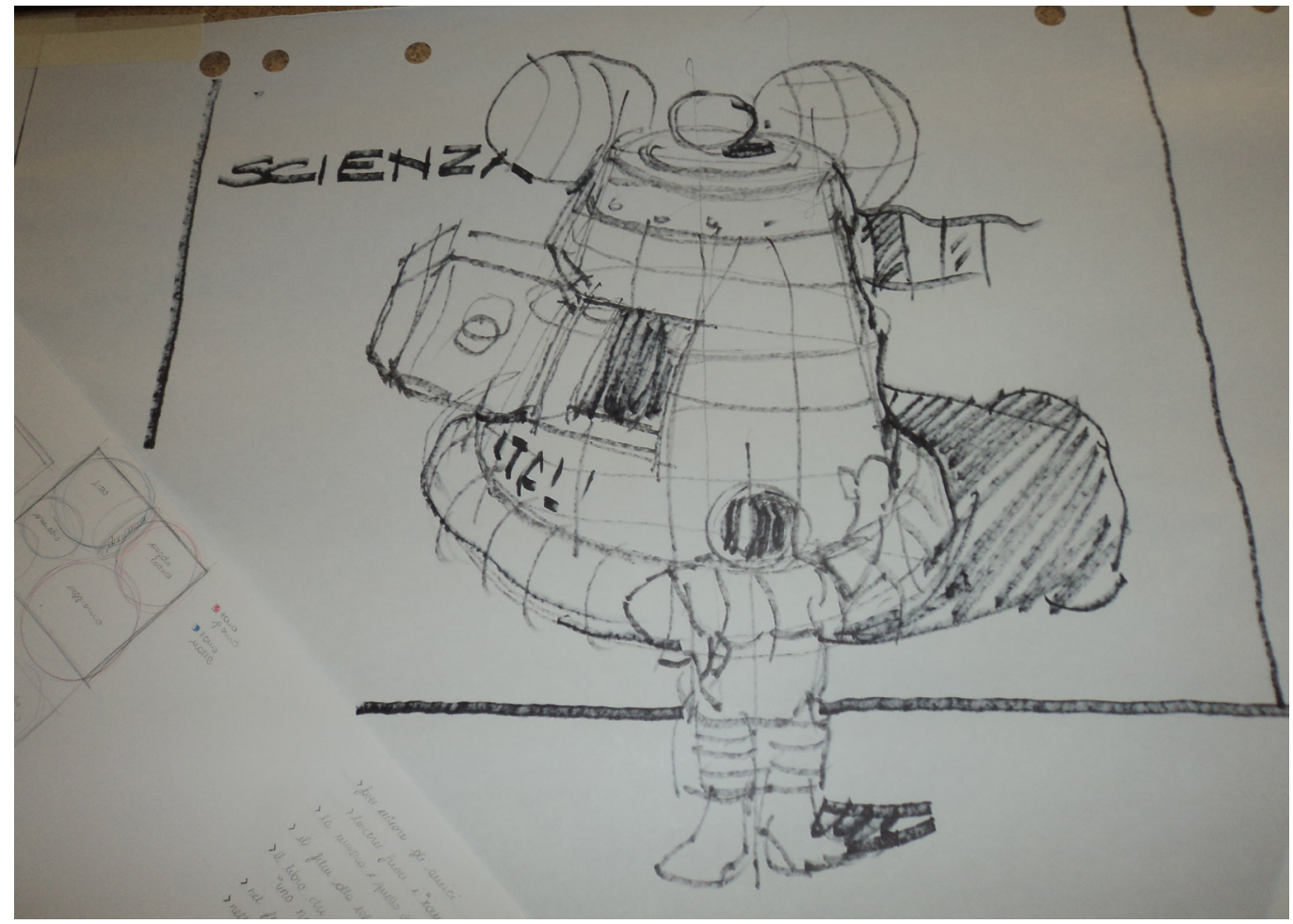

\section{Esemplificazione dei siti della ricerca}

Dopo un'analisi 'trasversale' sui possibili riferimenti culturali, da principio riconducibili al bagaglio della conoscenza personale, sono state individuate e prese in esame diverse tipologie abitative, cercando nella diversità dei luoghi un comune denominatore: una piccola architettura supportata e contestualizzata in un territorio dalla marcata connotazione paesaggistica. 


\section{L'Isola delle Rose (Rimini)}

L'utopico progetto di riferimento è stato realizzato alla fine degli anni '60 dal visionario ingegnere Giorgio Rosa, che al largo di Rimini (figg. 4, 5), costruì una piattaforma di circa 400 metri quadrati, a II km dalla costa, palificata a una profondità di 15 metri dalla superficie del mare. L'edificio si trasformò in una sorta di libera repubblica con tanto di governo, francobollo, moneta, bandiera e l'esperanto era la lingua corrente. Questo edificio, considerato non solo abusivo, ma sul confine delle acque territoriali del Mare Adriatico, creò un affare di stato, e dopo 57 giorni dalla sua costruzione, venne demolito con il tritolo dalla Marina Militare Italiana. Riscoperta attraverso un romanzo di Walter Veltroni, viene rivisitata dagli studenti con il disegno e la reinterpretazione del sogno dell'ingegnere bolognese a dimostrazione di come l'utopica isola su cui abitare (con sé stessi) è la speranza, che ci sia ancora un'isola da trovare.

Fig. 4. L'isola delle rose, la realizzazione dell'utopica idea, frutto della beat generation, di cui l'ingegnere Giorgio Rosa, si sentiva sicuramente appartenente, in una reinterpretazione grafica.

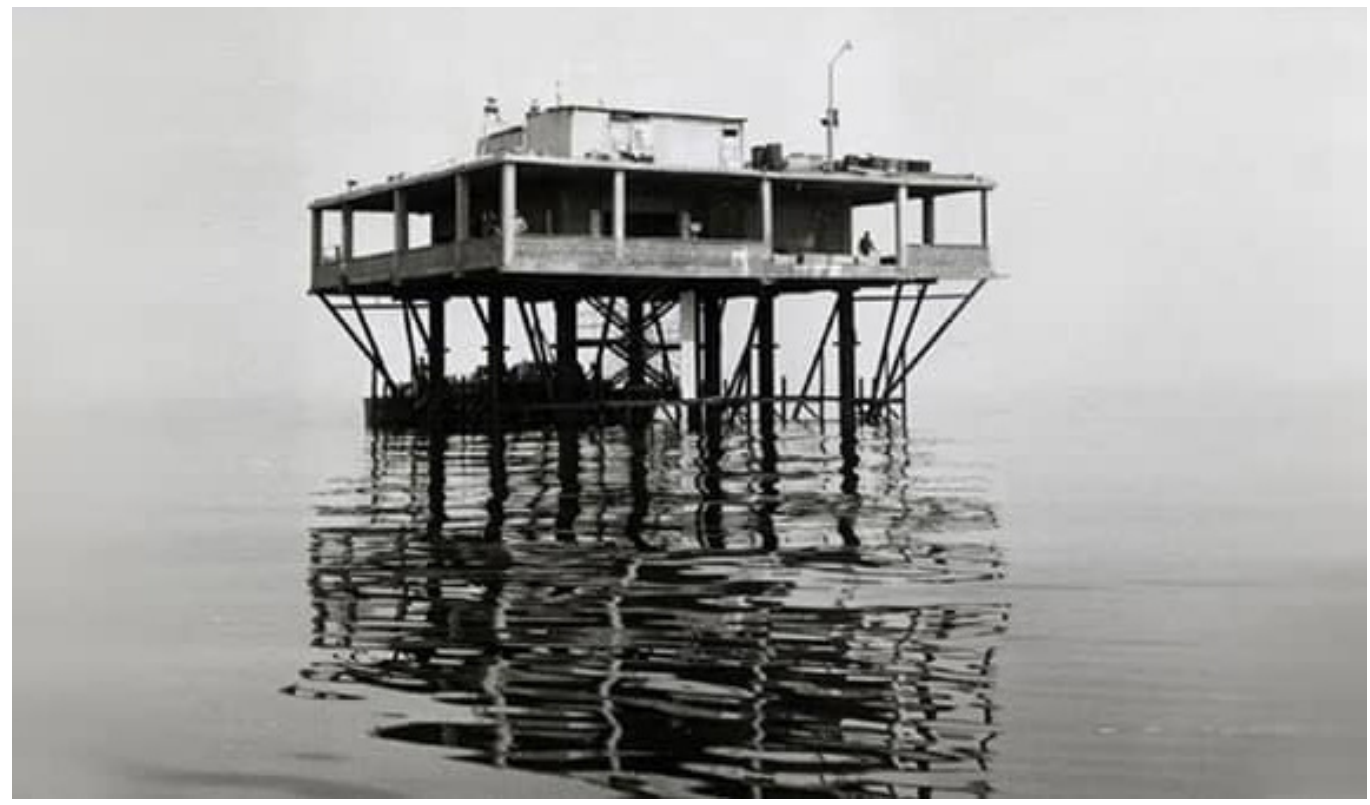

\section{Il portale della teleferica (Genova)}

Sul percorso di costa delle alture di Genova (figg. 6, 7), che adduce dalla settecentesca Torre Quezzi, per arrivare al Forte dei Ratti, sono ancora presenti due elementi della vecchia struttura per i cavi strallati della teleferica che sino a metà degli anni 60 portava l'estrazione cementizia della Cava di Genova in un punto di raccolta nel fondovalle della città (Val Bisagno). Immersi in un contesto paesaggistico straordinario, che nel tempo, a partire dal XVIII secolo, non ha subito radicali mutazioni, tra ginestre, terrazze coltivate a olivo e bosco ceduo, restano immobili nel tempo, disegnando con la loro perfetta volumetria una sorta di installazione architettonica permanente, ma senza più una precisa destinazione d'uso. Il doppio portale non ha un cattivo stato di conservazione, segno di una accurata mano d'opera del cemento armato, e i suoi due piccoli corpi di fabbrica sovrapposti $(4 \mathrm{~m} \times 3 \mathrm{~m})$, incorniciano nel cielo, dalla loro dismessa funzione, uno spazio ad quadratum. La fantasia di ogni studente-progettista ha saputo destinare questi spazi, con il vincolo di ripristinare la vecchia copertura a falde di legno, con cui erano storicamente coperti e sfruttando la pianta libera, che la struttura a pilastro gli consente, si sono garantiti la massima panoramicità dell'abitazione per sé stessi. 


\section{La stanza sull'albero (Brescia)}

Lo spazio abitativo, del progetto (fig. 8), in questo caso, si è limitato a una sola stanza di circa 12 metri quadrati $(3 \mathrm{~m} \times 4 \mathrm{~m})$, interamente realizzata in legno, e da costruirsi alla quota più accessibile di un platano, la cui altezza sfiora i 17 metri. La maestosa e bellissima essenza arborea trova la sua sede all'interno del cortile del Palazzo Martinengo Palatini. Costruito dal Conte Teofilo III Martinengo fra il I 672 e i primi anni del XVIII secolo, facendo da fondale alla Piazza del Mercato, esempio del barocco bresciano è sede del Rettorato. II platano è piantumato in una zona di scarsa frequenza e II cortile, sul quale affonda le radici da secoli è parzialmente usato a parcheggio delle biciclette. I progetti, finalizzati soprattutto al riscatto della visibilità della pianta, hanno avuto una esposizione in mostra. La vivacità degli elaborati grafici è sfociata in una serie di plastici, a conferma di come la maquette analogica, resti tra i migliori sistemi della rappresentazione, sia negli studi preliminari che in quelli definitivi. La geometria latente della foglia ricondotta a un disegno geometrico è stata uno degli l'elementi dominanti e di suggerimento agli input ghestaltici del progetto. II rilievo, eseguito per proporzioni, ha adottato volutamente per le misurazioni di massima, strumenti arcaici ed empirici quali ad esempio il palloncino aerostatico fissato a una cordicella, che nello 'stupore' della soluzione sono comunque riusciti a battere le principali quote in altezze per la rappresentazione dell'albero.

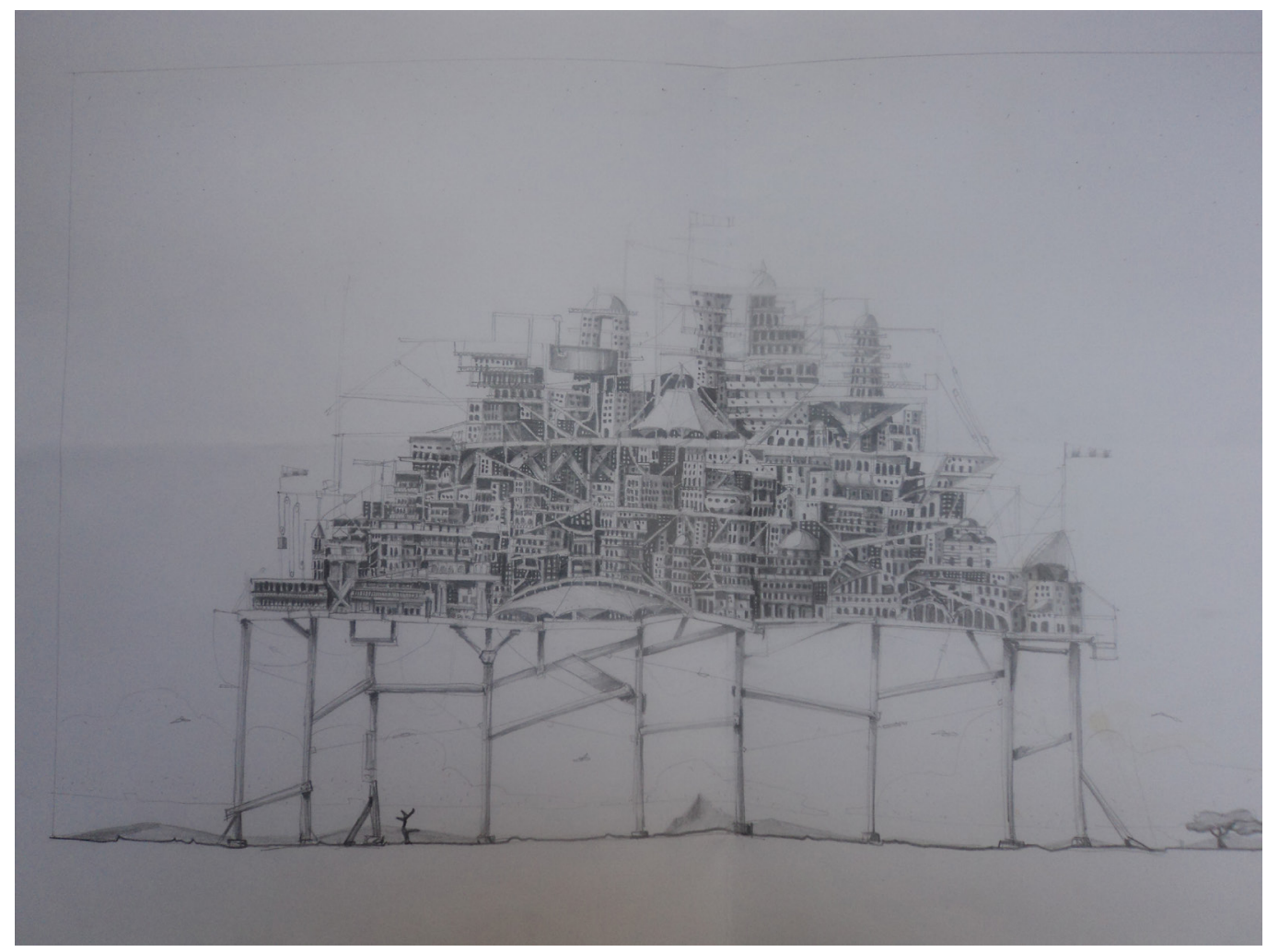

\section{Il Casello della RAV (Regia Alta Velocità) di Manerba del Garda (Brescia)}

Per la ricorrenza dei I00 anni (|928-20 | 8) dalla fondazione del Reparto AltaVelocità (RAV) diverse manifestazioni hanno visto interagire enti e 'attori' vari accomunati da affinità elettive culturali operanti sul territorio bresciano e la sua provincia lacustre.

L'Università degli Studi con i ricercatori del Dipartimento DICATAM, l'Aeronautica Militare rappresentata dal $6^{\circ}$ Stormo "Diavoli Rossi" di Ghedi (BS), e il Comune di Manerba del Gar- 
Figg. 6, 7. II portale della teleferica dell'ex cava cementifera a Genova (località Forte Ratti) ed isuoi progetti di 'spazio per sé stessi'. Esercitazione didattica, plastici in egno di balsa, tagliato $e$ sagomato in scala. da (BS), hanno in sinergia riscattato un momento storico ai molti sconosciuto, legato a quei luoghi, dove ancora oggi è visibile il rudere della piccola torretta predisposta negli anni 30 assieme a quella di Moniga, a casello, per le misurazioni della velocità degli idrovolanti, allora auspicanti il record di Alta Velocità della coppa internazionale Schneider. II primato fu allora conquistato sulle acque del lago prospicenti la rocca di Manerba dal Maggiore Francesco Agello, e a oggi resta insuperato.

Le dimensioni ridottissime di questo casello e soprattutto lo straordinario cannocchiale panoramico da cui si traguarda il Lago di Garda, sono stati l'elemento scatenante per i progetti, che si sono rivelati una Wunderkammer del proprio io e della fantasia di ogni loro autore.
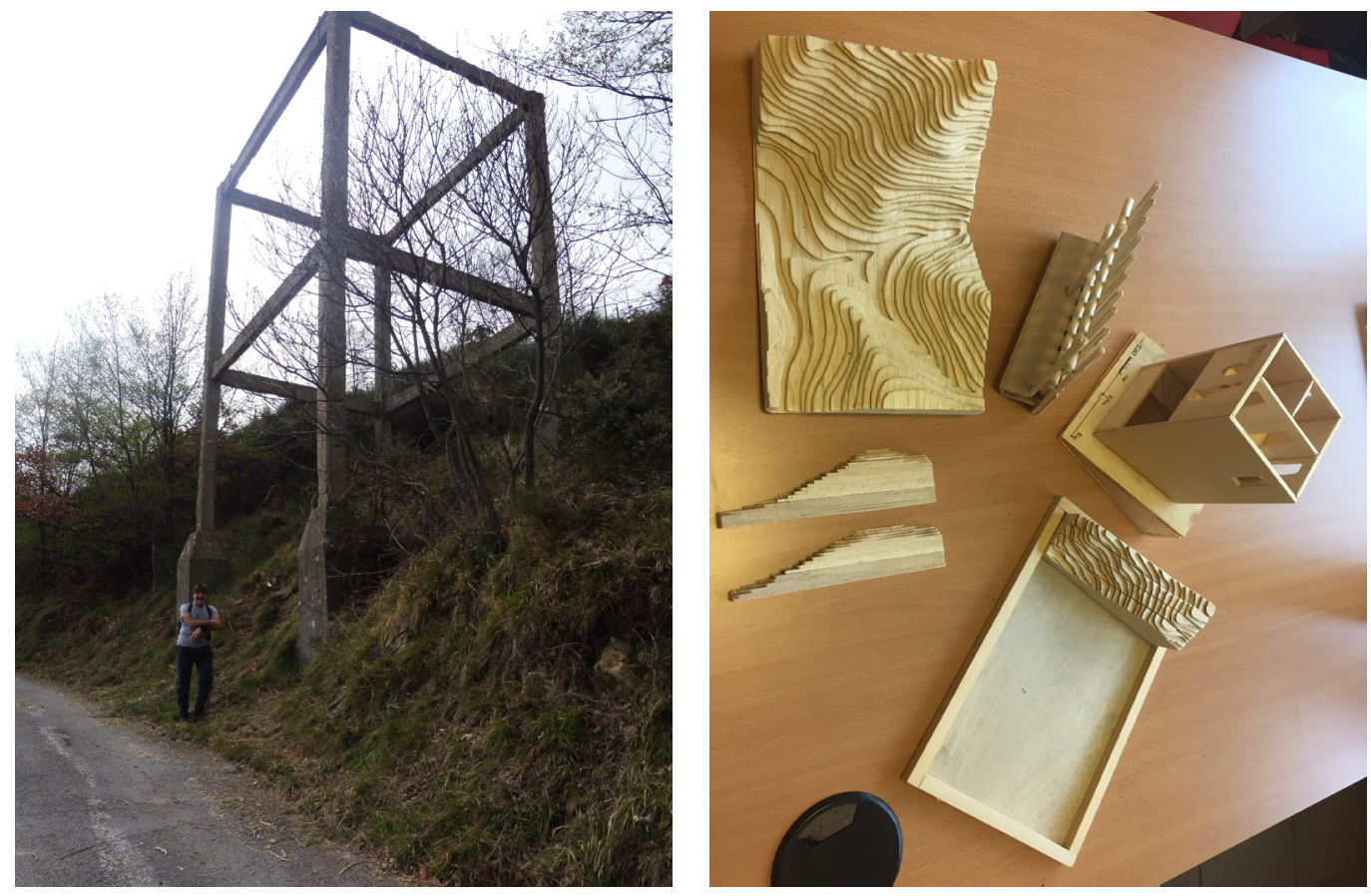

\section{Connessione - Finale}

Anch'io seppur oriundo, ho potuto rivedere in quei luoghi, il mio spazio dell'anima, trasportando la storia dell'evento in uno di quegli ambienti dove più amo abitare proprio con me stesso che è II "salone alla genovese" di casa stereotipo spaziale del tipico edificio storico ligure da dove vengono radialmente distribuite le altre stanze con le loro diverse destinazioni d'uso. Sulle decorazioni floreali del pavimento a tessera di mosaico del salone, campeggia l'elica di legno, che mio nonno materno negli anni '20 costruì a mano per un idrovolante che in quel periodo era in istanza all'idroscalo di Genova, molto simile al Macchi Castoldi del Maggiore Agello. La "vite aerea" come la definì nel 1493 Leonardo da Vinci suo inventore, è costruita con la sovrapposizione di strati lignei in acero rosso (normalmente se ne potevano contare dai 25 ai 50). II suo profilo verticale è stato tagliato da una sega a nastro su una dima, per poi essere successivamente tornito a mano, dopo aver naturalmente segnato 'il passo' vale a dire il punto di maggior sforzo dell'elica.

Spesso di fronte a questo ricordo di famiglia, amo ascoltare il flauto di Pan, scandire le note di C'era una volta in America con cui il maestro Ennio Morricone, musicò l'omonimo racconto cinematografico del regista Sergio Leone. Dopo la straordinaria esperienza di Manerba del Garda, la stessa musica, nello stesso spazio sarà commento di altri due racconti che potrei intitolare: l'uno "c'era una volta un costruttore di idrovolanti sul mare di Genova" e l'altro, in memoria dell'impresa del Maggiore Agello: "C'era una volta un pilota di idrovolanti sul lago di Garda".

... E "l'intagliatore di giada"? Questa è un'altra storia e la scriverò un'altra volta (figg. 9, I0). 
Fig. 8. "La stanza sull'albero", poster dell'evento. Disegni in tecnica mista dell'autore.

Figg. 9, 10."'L'intagliatore di giada e il costruttore di idrovolanti", poster dell'evento. Disegno a matita dell'autore.
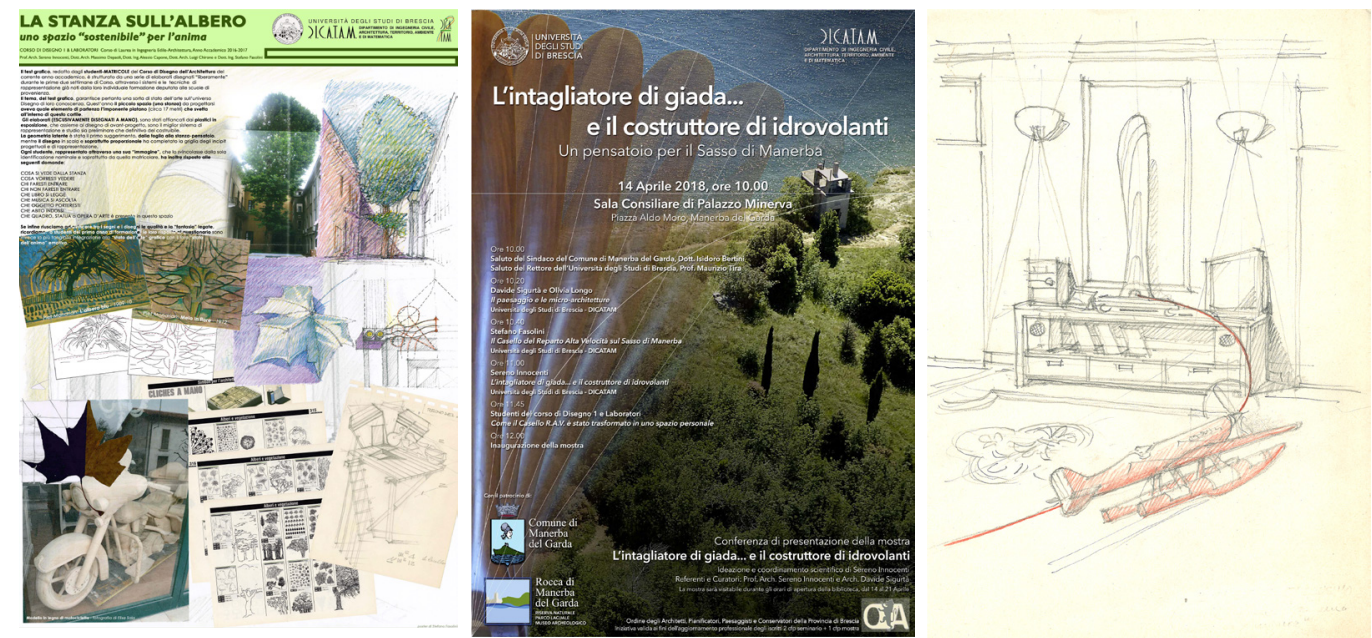

Riferimenti bibliografici

Berger J. (2017). Sul disegnare. Milano: II Saggiatore.

Defoe D. (17|9). La vita e strane sorprendenti arventure di Robinson Crusoe. London: Printed for W. Taylor.

Nancy J. L. (2017). Il disegno del piacere. A cura di M.Villani. Fano: Mimesis Edizioni.

Autore

Sereno Innocenti, Università di Brescia, sereno.innocenti@unibs.it

Per citare questo capitolo: Innocenti Sereno (2021). "Abitare con sé stessi". Dalla stanza sull'albero al Casello RAV (Reparto Alta Velocità) di Manerba del Garda (BS)/"Living With Youself". From the Tree Room to the Toll Booth RAV (High Speed Department) in Manerba del Garda (BS). In In Arena A Arena M Mediati D Raffa P (a cura di). Connettere Un disegno per annodare e tessere Lingugogi Distanze Tecnologie Atti de $42^{\circ}$ Convegno Internazionale dei Docenti delle Discipline dello Roppresentazione/Connecting Drawing for we Ling relationship. Languages Distances Technologies. Proceedings of the $42^{\text {th }}$ International Conference of Representation Disciplines Teachers. Milano: FrancoAngeli, pp. 825-840. 


\section{“Living With Yourself”. From the Tree Room to the Toll Booth RAV (High Speed Department) in Manerba del Garda (BS)}

Sereno Innocenti

\section{Abstract}

The trace of how a place, can turn into a 'place of the heart', you can find yourself in a interview given by the President of the Venice Biennale (2018) Paolo Baratta. On this principle, with simple but fundamental tools of representation (drawing and maquette) small relatively historical spaces are studied, but with strong landscape features of the guest site, with wich to be create a personal space, with wich you can 'live with youself'.

Keywords

dreams, curiosities, fantasy.

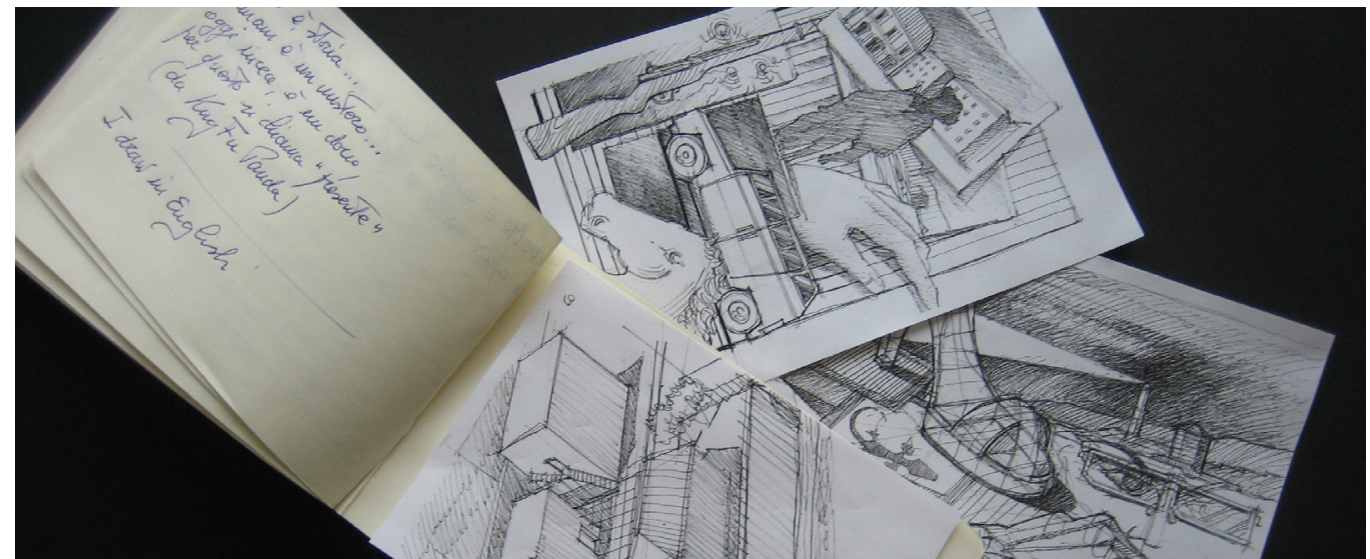




\section{Premise}

The urban planner and architect Kevin Andrew Linch, who has focused his research and activity on people's perception of the landscape I on the part of the people, he argues: "we all learn to read places, the way we learn to read a book. Reading a place means undestanding what could happen to you, and what it means and how yiu should be have, and finally how it is linked to other places".

The trace of how then a place instead can also become, a 'place of the heart' can ben found in an interview given by the President of the Venice Biennale of 2018, Paolo Baratta who answered the question:

"I really have a lot of them, some I recognize the as such after many years, you don't baptize, them on the first impact. Place of the heart is a definition imbued with some feeling, I prefer to say place of the recognized heart, say a part of a reality; this is, after all, everyone's wish. The sense of space, a value that we must recognize,rather than atmospher, I prefer to talk about how much certain places know how to give by making you recognize yourself as the recipient of the gift".

On these principies every year, with the freshmen students of the Drawing Course, during the first weeks of study, through 'grafic-creative test' we experience the design and relief of a small space already existing.with a particolar landscape character of the host site, to be allocated to a sorto of "thinker" or "personal space" to be trasformed in place of the heart to live with yourself.

Fig. I. Cinema, tecnica, science and literatue, comparative tip for the comparative tip for the comparative project of the micro space in which 'to dwell with yourself' (pen drawings of the author).

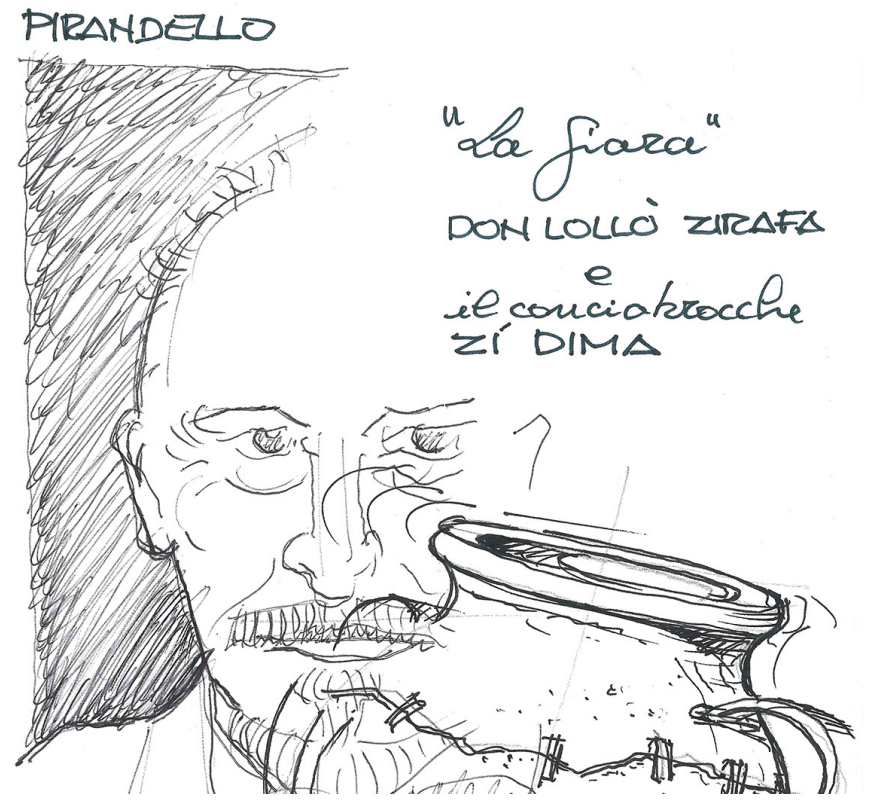

\section{Methodology}

The space is studied through a dichotomy research between reason and feeling, wich distinguishes potential and future from site inhabitants. The space of reason, stigmatized by the cultural baggage and possible intrinsic passion of the individual scholar, is drawn manually through sketches, tecnical drawing and analogplastics, designed to represent those micro uses that respond to functions not strictly related to living, but the very simply an attempt is made to make this spacetightly sewn on the personalità of its inhabitant/designer.The anwer to the questions: who would you host or who would not want to host in the space; that music is heard; what book is read; what films can be seen; that work of art is displayed; that I dressor that food and drink is tasted, to wich the only written answer is given, becomes the litmus test of the state of soul of the possible inhabitant of this space. 
The teaching of drawing has always played a fundamental role in the schools of Engineering and Architecture, and sometimes and a little improperly it is considered only an artistic discipline; but in art schools of the past, the drawing room took on a simbol configuation even in the topographic distribution of spaces. Inside the presence of drawings hanging on the walls, wooden maquettes, architectural friezes and a rich gipsoteca gave it a particularan artistic discipline. But in art schools of the past, the drawing room took on a simboli configuration even in the topografhic distribution of spaces. Inside the presence of drawing hanging on the walls, wooden maquettes, architectural friezes and the classroom following a tradition now lost was dedicated to Minerva; goddess of thought of rationality, blossomed from Zeus' brain symbol of design to the point of inspiring Ulysses the project for hiTrojan horse. This concept of space to create, suggested from the writings of Atillio Pizzigoni, is almost utopian in a time where you think, comunicate and then draw digitally, but within the drawing laboratories, the project and thought will always have to be traced by the pencil! "the dream is like the evil one, he never dies", said director Mario Monicelli, and it is in the dreams of every future architect, every future engineer, the project of great works and large spaces, but the more simple and reduced the projects, the more complex the solutions and the more widespread care is required in detail, there is a personal space, however smalli it is, I believe that every individual can become the best designer for this space, naturally choosing for the latter the best designer for this space, naturale choosing for the latter tue best landscapes in which it is used and tue best view on wich to look out.

Fig. 2. Cinema, tecnica, science and literatue, can become a creative comparative tip for the comparative project of the micro space in which to dwell with yourself (pen drawings of the author)

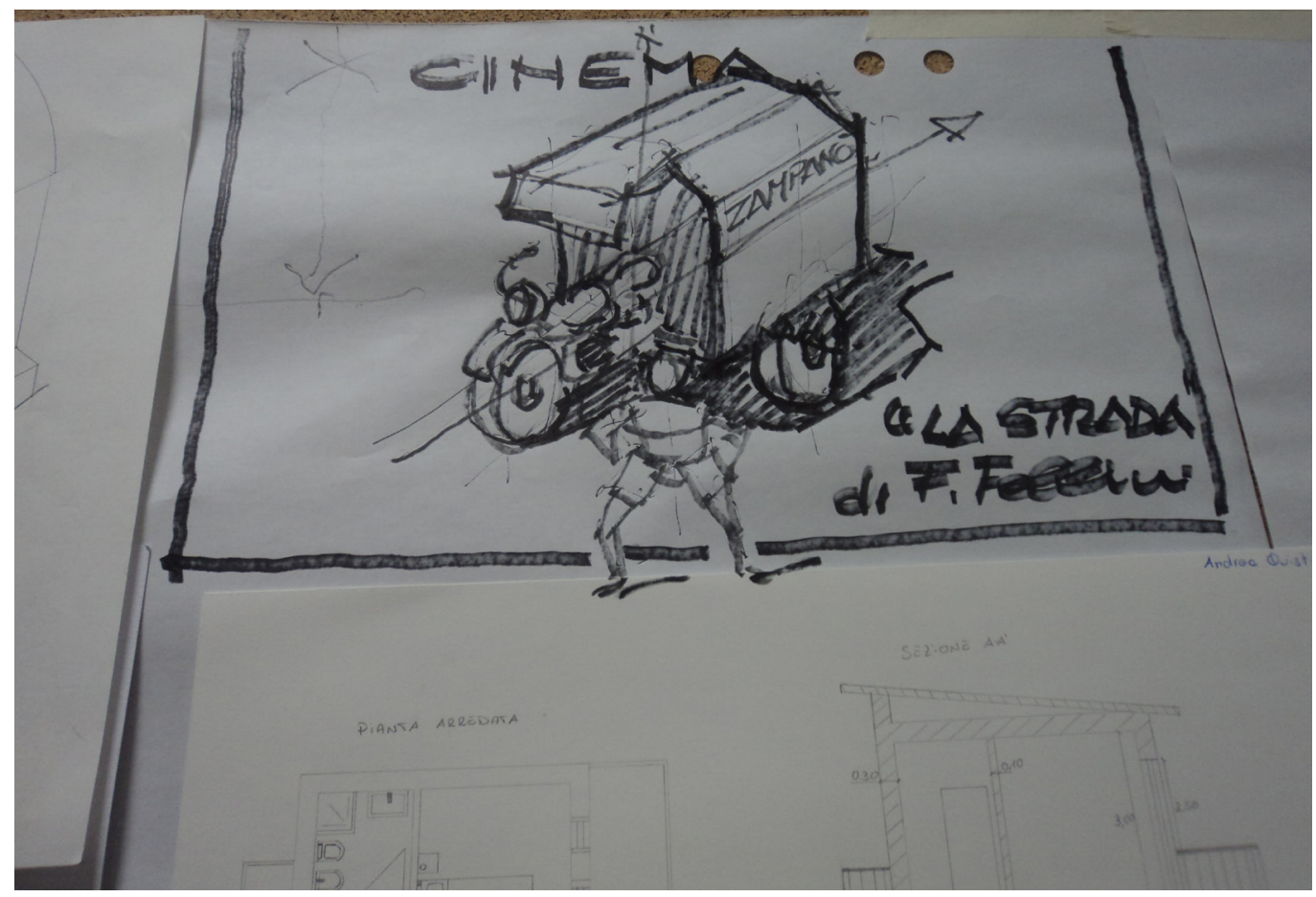

\section{Cultural references, from filmographi to architecture}

Cinema, science, technology as well as literature and philosophy (figs. I-3) have been synoptic examples for inductive suggestions and stimulus to creativity of the space projet for themselves. Federico Fellini in the film La strada with wich in 1957 he won the Oscar for best foreign films, draws as he used to do, a small 'travelling house' for the protagonist of his masterpiece of celluloid. The jumper and imbonitor Zampanò, masterfully played by the actor Antony Quinn and Giulietta Masina, wife of the master, as Jasmine, live in the cramped space of three-weeled motorcycle, built specifically on the basis of the Sertum motorcycle, 
whose tarparli part of the chassis, is designed by the Romagna director, like a terrible monster, that swallows them and devours them. The motor truck thus becomes their travelling home, a space in which, however, they live a melancholy life of hardship, motivated by overlooking the landscape o fan Italy destroyed by war and bombing, if in metaphor, from the stars of cinema, we move on to the stars of the firmament, we can considera s another example, of 'minimum habitability' and with different living conditions in the absence of Herart's gravity, the environments to inhabit the Soyuz that brought back from space to Kazakhistan Commander Paolo Nespoli and his space crew. Even literature, suggests traces for microspaces. Luigi Pirandello, for example, builds his famous dramaturgical work around "Ia giara", where Don Lolò Zifara and the tanning company Zi Dima, are the protagonists of the theatrical schedule, part of which takes place right inside a large oil garden.

The Greek philosopher Diogenes, history has handed down to us that the lived in a barrel, and Renzo Piano, in 2013, 'baptizes' with the same name the project for the Vitra of the "Meditation hut" consisting o fan eco-sustainaible mobile housing unit with a very small ergonomically functional dimensions $(2 m \times 2 m)$ from the cubage, which does not exceed 3 cubic meters in volume and weighing one volume and the weight of a ton, building a prototype on the Campus of Weil Am Rhein on the Rhine. In an interview he stated that the minimum dwelling was a theme that had haunted him since his hearly yars at the University. Equally difficult was the challenge of a group of students from the Harvard Graduate School of design who have designed an 'innovative refuge' able to withstand thunderstorms, snows and alpine winds on a terrain refractory to solidity such as karst. With the help of professional architects and structural engineers, a minimalist bivouac has been built in Slovenia on Mount Skuta, taking the concept of panoramic to the extreme.

Fig. 3. Cinema, tecnica, science and literatue, can become a creative comparative tip for the comparative project of the micro space in which 'to dwell with yourself' (pen drawings of the author)

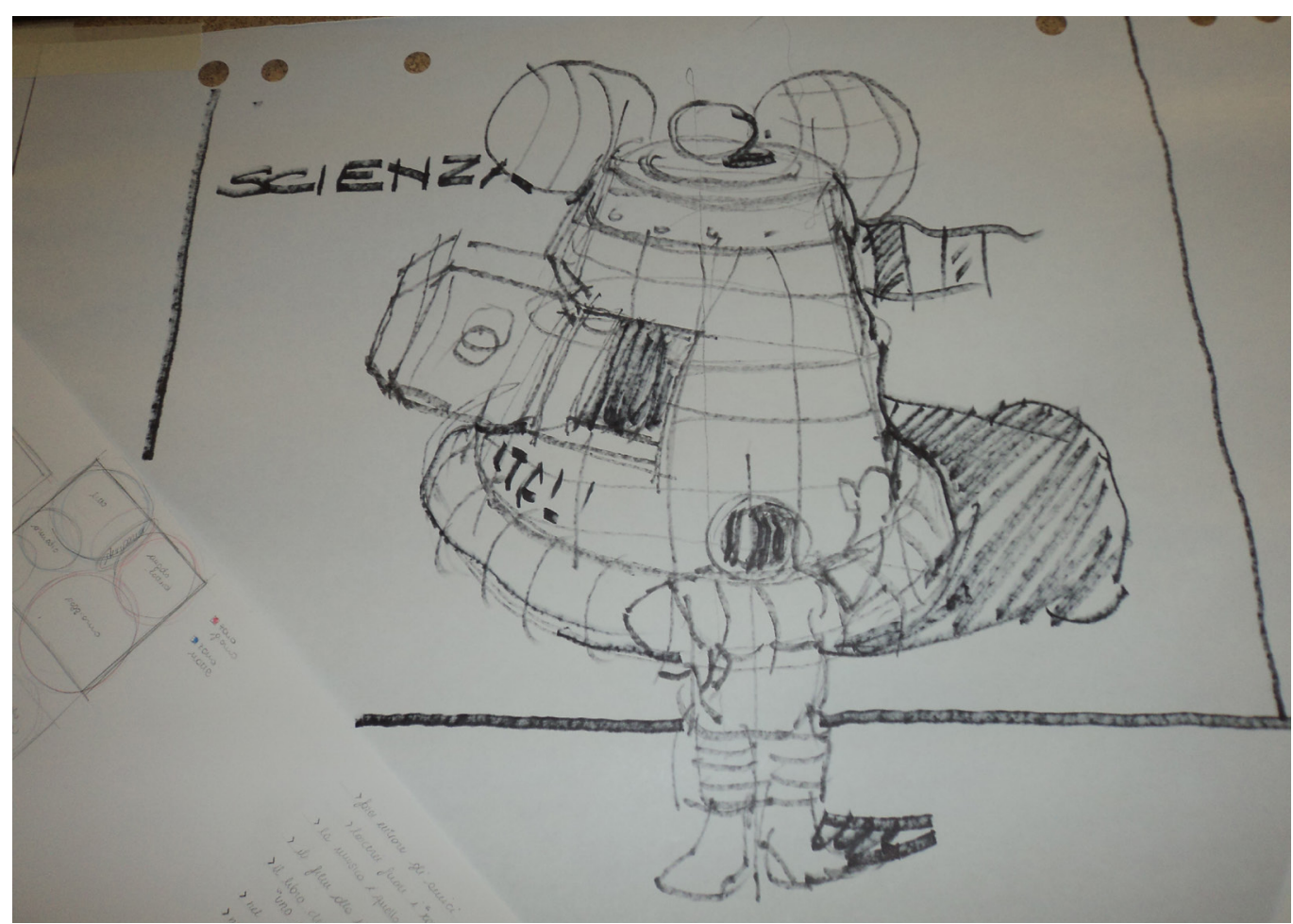

\section{Exemplification of research sites}

After a cross-cutting analysis of possible cultural reference from the beginning attribuitable to the baggage of personal knowledge they have been identified different types of housing have been identified, looking in the diversity of places a common denominator: a small supported and contextualized architecture in a territory with a marked landscape connotation. 


\section{L'Island of Roses (Rimini)}

The utopian reference project (figs. 4, 5), was realized at the end of the 60s by the visionary engineer, Giorgio Rosa, who off Rimini, built a platform of about 400 square meters, II km from the coast, piled at a depth of 15 meters from the sea surface. The building turned into a kind of free Republic complete with governement, stamp, currency and flag and Esperanto was the current language. This building, considered not only abusive, but on the border of the territorial waters of the Adriatic Sea, created a state affaie, and after 57 days of its construction, it was demolished with the tritol by the Italian Navy. Rediscovered through a novel by Walter Veltroni, it is revisited with the students design and reinterpratation of the dream of the Bolognese engineer demonstrating how the utopian Island on which to dwell (with oneself) is hope, that there is still an Island to find.

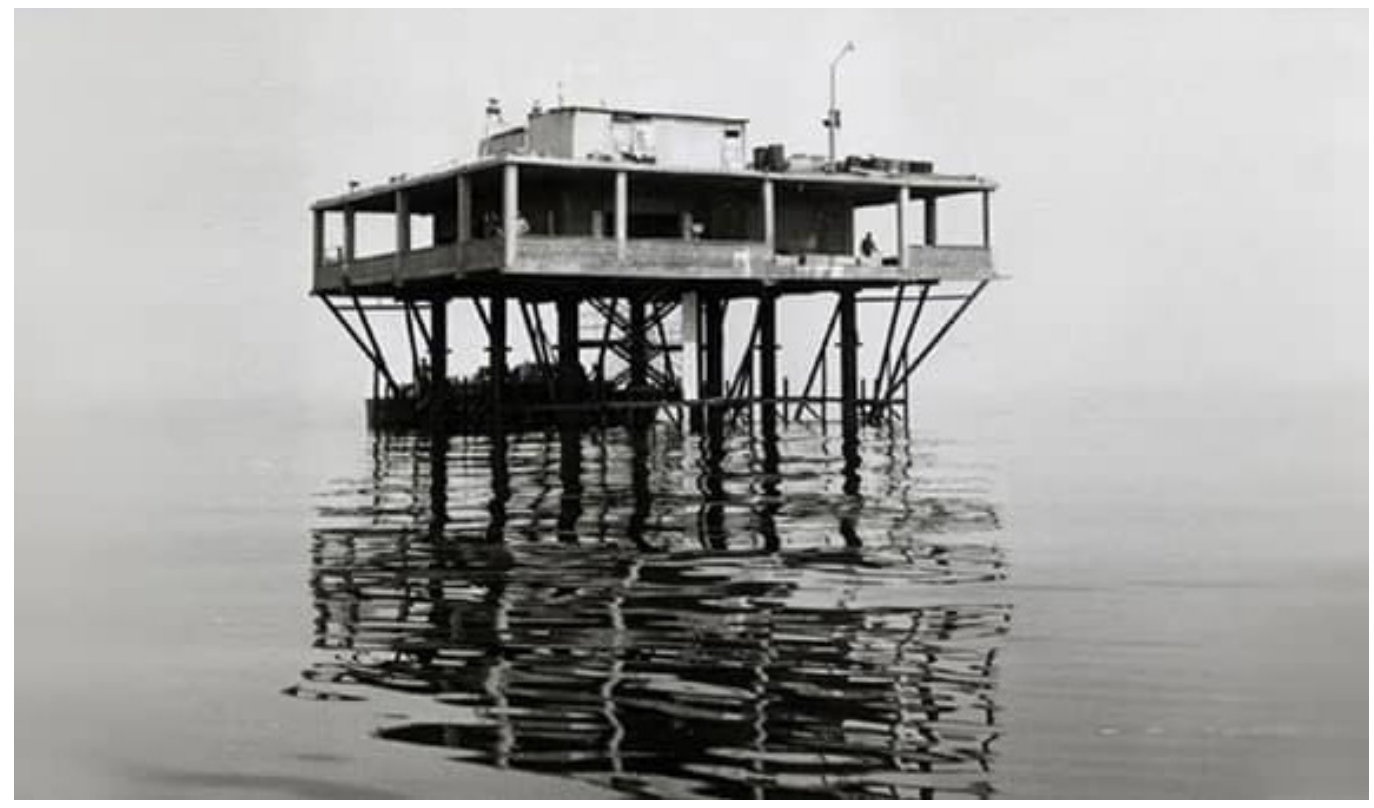

\section{The portalof the cable car (Genoa)}

On the coast path of the heights of Genoa (figs. 6, 7), which leads from the eighteenth-century Torre Quezzi, to get to the forte dei Ratti, there are still two elements of the old structure for cable car that until the mid-60s city (Val Bisagno). Immersed in an extraordinary landscape context, which over time, since the eighteenth century, has not undergone radical mutation, among brooms, terraces cultivated with olive trees and coppice woods, remain immobile over time, drawing with their perfect volume a sorto of permanent architectural installationn, but no longer a intended use. The double portal, has no bad state of preservation, a sign of a accurate old man-labour of reinforced concrete and Its two small overlapping bodies $(4 \mathrm{~m} \times 3 \mathrm{~m})$ frame in the sky, from therir disused function, an ad quadratum space.

The imagination of each designer, he was able to allocate these spaces, with the constraint of restoring the old wooden roof, with which they were historically covered, and instead exploiting the free plant, which the pillar structure allowed him, in order to guarantee the maximum panoramic view of the perces house itself has been quaranted of the dwelling for themselves. 


\section{The room on the tree (Brescia)}

The living space, of the project (fig. 8), in this case, was limited to a single room of about 12 square meters $(3 \mathrm{~m} \times 4 \mathrm{~m})$, entirely made of wood, and to be built at the accessibile altitude of un plane, whose heihgt is almost 17 meters. The Majestic and beatiful tree essence, finds its headquarters inside the court yard of the Palazzo Martinengo Palatini. Built by Count Theophilus III Martinengo between 1672 and the early I 8th century, acting as a backdrop to the Piazza del Mercato, an example of the Brescia baroque is home to the Rectorate,The plane tree is planted in an area of low frequency and the courtyard, on which its roots have been rooted for centuries, is partially used to park bicycles. The projects, aimed mainly at redeeming the visibility of the plant, had an exhibition on display. The liveliness of the grafic work sit has representation through drawing, has resulted in a series of plastics, confirming how the analog maquette, remains, among the best systems of representation, both in preliminary and final studies. The latent geometry of the leaf, traced back to a geometric design, was one of the ghelstatics of the project the survey carried out in proportions, deliberately adepte for the general measurements archaic and empirical instruments such as for example, the balloon attached to a string that in the astonishment of the solution they still managed to eat the main dimensions in heighrt for the representation of the tree. The survey proportional with empirical measurement sysrems, such as 'the balloon aerostatic' fixed to a cord, to bead some heights of difficult accessibilità, have guaranteed the return in principle for the representation of the tree.

Fig. 5. The island of roses the realzation of the utopian idea, fruit of the beat generation of which
the engineer Giorgio Rosa, surely felt belonging in a graphic reinterpretation. Teaching exercise, pencildrawing.

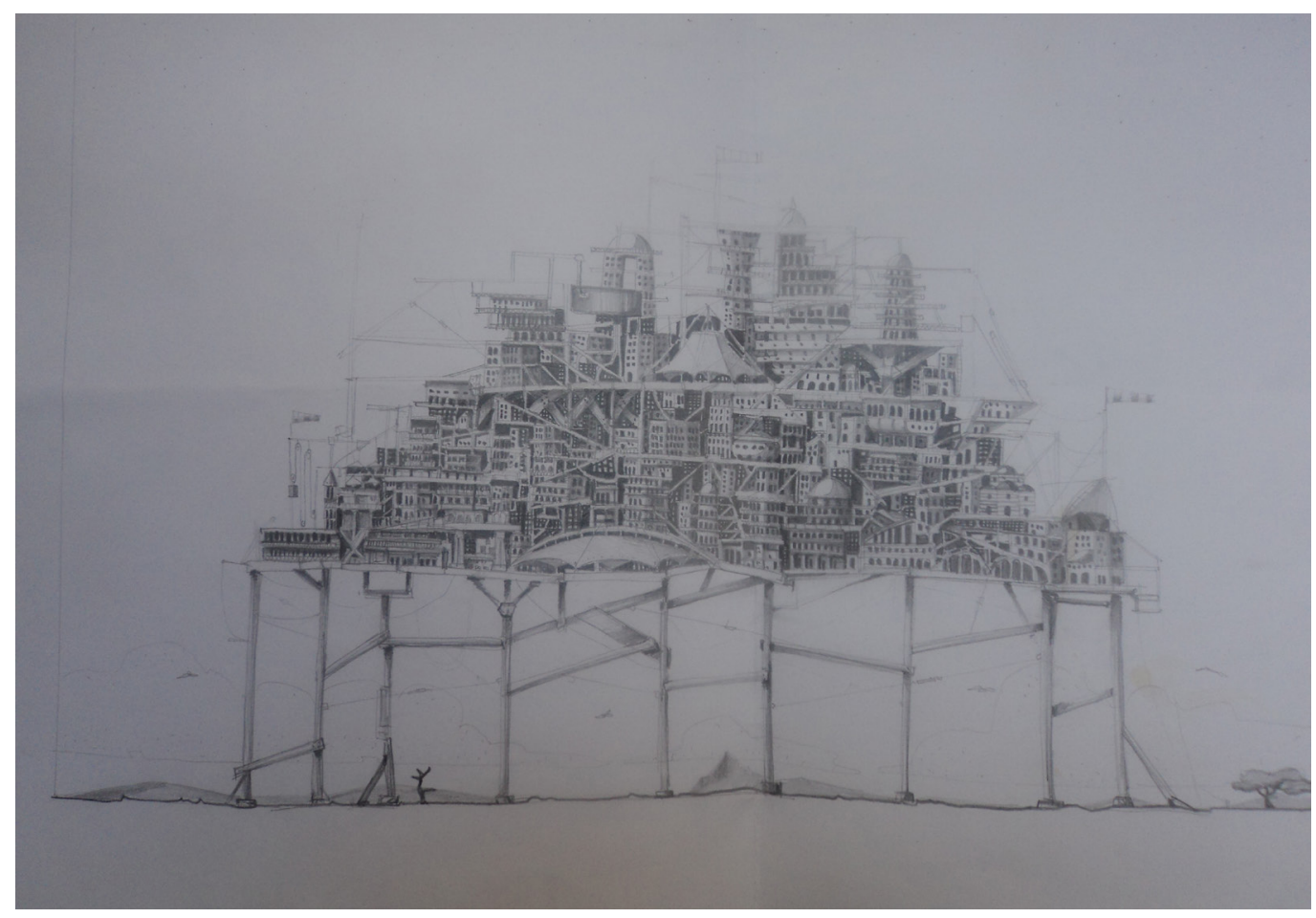

The reason for the Toll Booth of the RAV (Regia Alta Velocità) di Manerba del Garda (Brescia)

For the anniversary of the 100 years (1928-2018) since the foundation of the High Speed Department (RAV) several events have seen the inetaction of various 'actors' bodies united by cultural elective affinities operating in the Brescia area and its lake province.The University of Studies with reseaechers from the DICATAM Department, the Air Force represented 
by the 6th Wing "Diavoli Rossi" of Ghedi (BS), and the Municipality of Manerba del Garda (BS), have in synergy redeemed a historical moment to the many unknown, linked to those places, where even today is visible the ruins of the small visible the ruins of the small turret prepared in the 30s together with that of Moniga at the toll booth, for the measurements of the velocity at the flyers, then hoping for the record high-speed International cup Schneider, the primacy was the conquered on the waters of the lake overlooking the fortrss of handcuffs from the major Francesco Agello and to today, remains unsurpassed. Its small size and above all the extraordinary panoramic telescope from which Lake Garda is overlooked, wew the trigger of the projects, wich turned out to be a Wunderkammer of their own self and the imagination of each of their authors.

Figs. 6, 7.The portal of the cableway of the former cement quarry in Genoa (location of Forte dei Ratti) and his plans of 'space for themselves'. Educational exercise bals wood, cut and shake in scale.
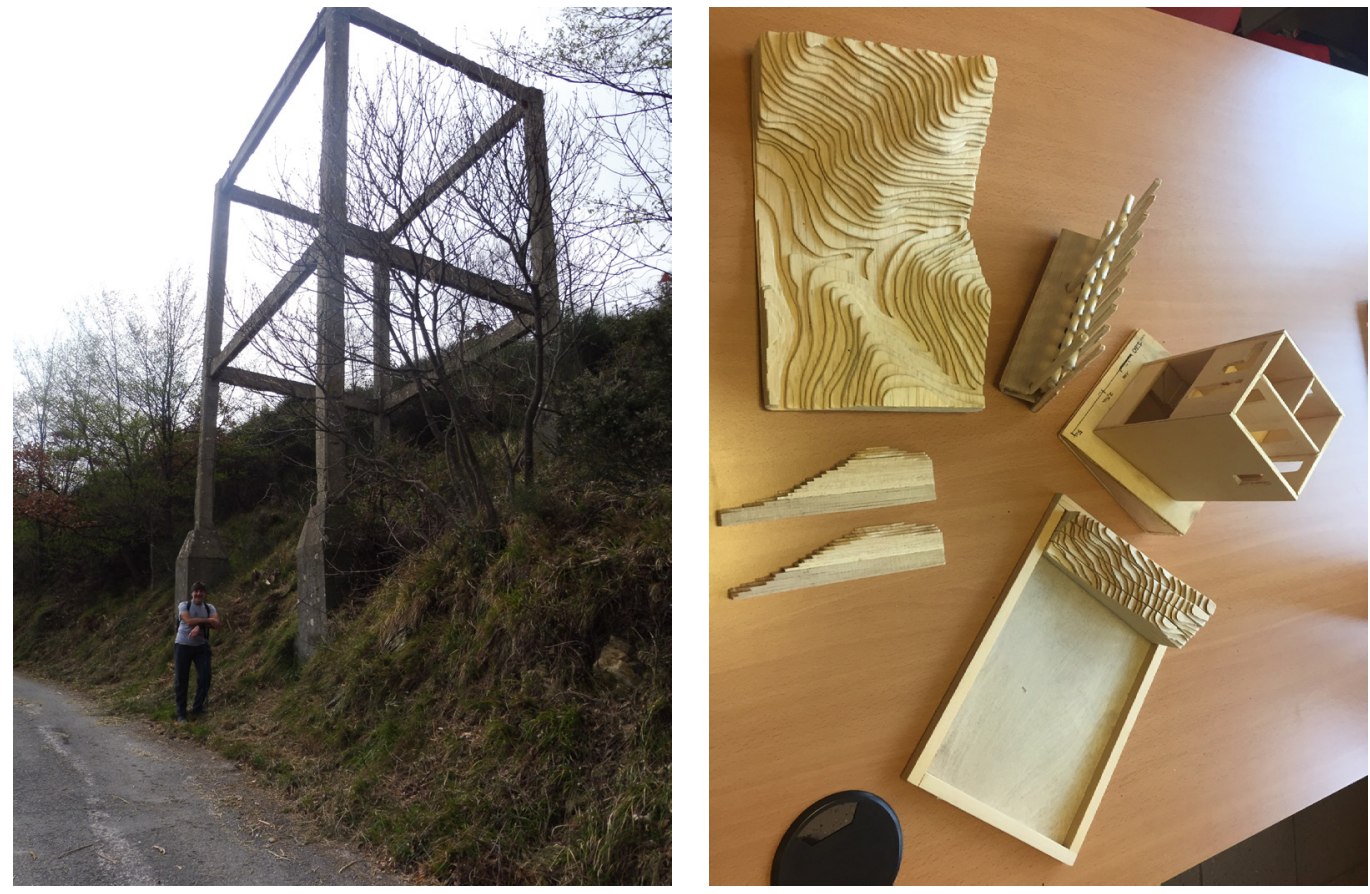

\section{Final connection}

Even thug I was oriundo, I was able to see in those places, my space of the soul, trasporting the history of the event to one of those environments where I love to live with myself that, is the 'Genoese salon' of the house; spatial stereotipe of the tipical Ligurian historical building from where the other rooms are radially distributed with their uses, on the floral decorations of the mosaic tile floor of the salon, stands the wooden propeller, which my maternal grandfather in the 1920s built by hand for a seaplane that at time was in demand at the genoa hydroscalo, very similar to the Macchi Castoldi of major Agello. The "aerial screw" a sit was defined in 1493 Leonardo da Vinci its inventor, is built with the overlapping of wooden layers in red maple (normally 25 to 50 ) could be counted; its vertical profile was cut by a band saw on a dima, and then turned by hand, after naturally marking 'the step' that is the point of greatest effort of the propeller.

Often in front of this family memory, I love listening to Pan's flute, scan the notes of Once upon a time in America that maestro Ennio Morricone, he wrote the director's film tale of the same name of music director Sergio Leone.

Now after the extraordinary experience of Manerba, the same music, in the same space, will be commentary on two other stories that I could name: one "there was a seaplane manufacturer on the sea of Genoa" and the other, in memory of major Agello: "Once upon a time there was a seaplane pilot on Lake Garda" ... and "the jade carver"? This is another story, and I'm going to write it again (figs. 9, I0). 
Fig. 8." The room on the tree". Poster of the event. Mixed-technique drawings by the author.

Figs. 9, 10.The jade carver and seaplane manufacture, poster of the event. Pencil drawing of the author.
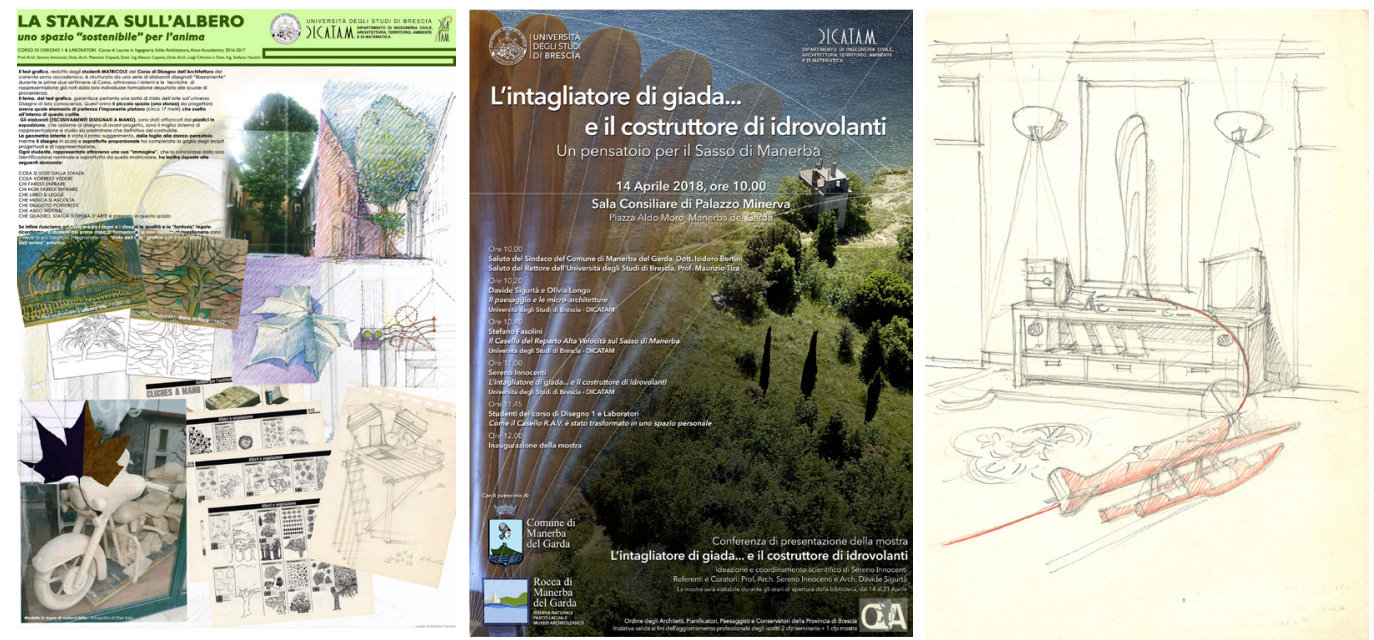

References

Berger J. (2017). Sul disegnare. Milano: II Saggiatore.

Defoe D. ( 1719). La vita e strane sorprendenti arventure di Robinson Crusoe. London: Printed for W. Taylor.

Nancy J. L. (2017). Il disegno del piacere. A cura di M.Villani. Fano: Mimesis Edizioni.
Author

Sereno Innocenti, Università di Brescia, sereno.innocenti@unibs.it

To cite this chapter. Innocenti Sereno (202I). "Abitare con sé stessi". Dalla stanza sull'albero al Casello RAV (Reparto Alta Velocità) di Manerba del Garda (BS)/"Living With Youself". From the Tree Room to the Toll Booth RAV (High Speed Department) in Manerba del Garda (BS). In Arena A Arena M Mediati D Raffa P (a cura di) Connettere Un disegno per annodare e tessere Linguegri Distanze Tecnologie Attidel $42^{\circ}$ Convegno Internazionale dei Docenti delle Discipline della Rappresentazione/Connecting. Drawing for weaving relationship. Languages Distances Technologies. Proceedings of the 42 $2^{\text {th }}$ International Conference of Representation Disciplines Teachers. Milano: FrancoAngeli, pp. 825-840. 